\title{
Translational lab-to-clinic hurdles in stem cell therapy
}

\author{
Sydney Corey, Trenton Lippert and Cesar V. Borlongan*
}

\begin{abstract}
Several experimental therapeutics have been demonstrated to be safe and effective in animal models of neurological disorders, but have failed when they reached the clinic. Postulated factors that affected the poor clinical outcomes include the lack of proper treatment controls and clinically relevant animal models. This failure of lab-to-clinic translation has plagued many neuroprotective drugs for stroke. With this in mind, the stem cell therapy field has cautiously approached translating stem cell products for clinical application, in that a negative clinical trial may hinder the entire regenerative medicine therapeutics. Here, we discuss the many translational challenges associated with stem cell therapy in the setting of stroke.
\end{abstract}

Keywords: Physical therapy, Cerebral ischemia, Neurogenesis, Cell transplantation

\section{Background}

\section{Rehabilitation therapy and stem cell transplantation}

The combination treatments of stem cell therapy and rehabilitation therapy remain a key challenge to accomplish optimal clinical benefits for stroke patients. Of note, the most recent consortium of Stem Cell Therapeutics as an Emerging Paradigm for Stroke or STEPS 3 made strides in analyzing stem cell therapy with rehabilitation therapy to identify their individual therapeutic effects [1, 2], as well as examining whether a combination of these two treatments could improve stroke outcomes. Despite stroke rehabilitation being a standard treatment in stroke patients [3], laboratory studies have largely overlooked the use of rehabilitation therapy in experimental trials, this marks a serious disconnect between the laboratory and clinical settings. Many studies have shown that rehabilitation, or exercise, positively impacts the effects of endogenous stem cell therapy. The concept that exercise led to enhanced neurogenesis was brought to the forefront by Dr. Gage and colleagues [4]. Specifically, this paper shows that new cells nearly doubled in the hippocampus following 12 days of daily running. Additionally, Dr. Mattson's paper “take away my food, and let me run" emphasizes the benefits of exercise and healthy diet [5]. Based on these pioneering laboratory studies, exercises such as running has been

\footnotetext{
* Correspondence: cborlong@health.usf.edu

Center of Excellence for Aging and Brain Repair, Department of

Neurosurgery and Brain Repair, University of South Florida Morsani College of Medicine, 12901 Bruce B. Downs Blvd, Tampa, FL 33612, USA
}

shown to combat the effects of age-related disorders, including AD [6], PD [7], stroke [8], and TBI [9]. Our paper in 2007 [10], shows detrimental effects of suppressing exercise were observed using the hindlimb suspension model, where animals were subjected to hindlimb suspension for 2 weeks. Following the inactivity period, an examination of the animal's brains revealed decreased neurogenesis in both the hippocampus and SVZ. These animals displayed the lack of exercise approximately resembling the example of aged patients who lack a daily exercise regimen. In accordance with this paradigm, younger animals exhibited less severe deficits in hippocampal neurogenesis following the hindlimb suspension, in comparison to the older group [11]. The hindlimb suspension model was altered to examine the effects of a "restraint stress" (animal placed in conical tube with little to no directional movement) [12, 13], in which females exhibited more severe hippocampal effects [14]. Perhaps future studies, as in our paper [15], will integrate rehabilitation therapy with existing models of age-related disorders (e.g., $\mathrm{AD}$, stroke, $\mathrm{PD}, \mathrm{TBI}$ ) and provide further insight into the relationship between lack of physical activity and neurogenesis, leading to novel theories on functional benefits of rehabilitation and stem cell therapy [16].

\section{Finding viable stem cell sources}

Due to a federal moratorium on $\mathrm{NIH}$ funds, throughout the early 2000s, directed at embryonic stem cell 
research, adult stem cells have approximately a 10-year head start over ES cells simply due to lack of funding. Therefore, adult stem cells, specifically bone marrowderived mesenchymal stromal cells, are the most attractive stem cell source with potential clinical applications. A small portion of clinical trials are already testing adult stem cells in stroke patients. We already have an established understanding of the effective cell does, pathway and timing of injection as well as an adequate safety analysis of these cells. The method of transport is still not fully understood, which warrants further research into this mechanism. This data we gain from adult stem cells may contribute to the modification and advancement of ES cells' clinical application, as well as other cell sources, as in iPSCs. Additionally, it is necessary to keep an open mind in regards to other potential cell sources, including very small embryonic-like (VSELs) [17], multilineagedifferentiating stress-enduring (Muse) cells [18], and the recently described region-selective pluripotent stem cells (rsPSCs) [19]. While bioethical issues spark controversy with the latter cells, the most attractive source of stem cells depends primarily on the cells' therapeutic potential. Despite the importance of known entities of stem cells for preliminary benchmark to qualify for transplantable stem cells, our aim is to demonstrate that stem cells are beneficial and effective. Although there is a tested population of stem cells, they are neither safe or effective which ultimately invalidates any possible clinical benefits An evaluation of the currently available stem cells may present a novel view of the ideal cell type for specific stroke-targeted disease stage and pathology [20].

\section{Safe and effective stem cell delivery route}

The most favorable cell delivery route depends primarily on which disease is targeted. This area is where pre-clinical research is propelling the decisions regarding the delivery pathway. As found through experimental stroke, stem cells use the chemokine signal CXCR4-SDF1 to reach the ischemic brain from the periphery, where they're injected.

The peak of the chemokine signal appears within days after stroke, although remaining elevated for long periods, which indicates that intravenous or intra-arterial routes of administration are preferred for acute stroke. However, the intracerebral (IC) approach is the ideal method of administration for chronic stroke patients because the chemokine signal is not as strong as the early stage [21]. Several factors must be considered in determining the choice of stem cell transplant route. Considering that stroke is now regarded as a chronic disease, repeated transplants may be required to combat the several secondary cell death events such as inflammation. Further research is still necessary to examine the safety and efficacy of these repeated transplants. Additionally, studies have demonstrated that CNS bioavailability may be necessary for successful treatment of stroke [22], and that targeting the spleen to reduce the secondary cell death events may be equally beneficial for functional recovery [23]. Due to this, numerous aspects must be taken into account for deciding the stem cell transplant pathway.

\section{Clinically relevant animal models for testing cell therapy}

Animal models of stroke, specifically small rodents, have played a vital role in translational from the laboratory to the clinic [24]. However, we recognize the limitations of the rodent stroke models, as demonstrated by many promising laboratory results which are unsuccessful in the clinical setting. Numerous research groups attribute this to the small white matter in the rodent brain that is inconsistent with the structure of the human brain. While recent studies have created specific models to produce white matter injury in rodents $[25,26]$, pursuing alternative models, such as larger animals, may increase success of clinical translation if these issues of misrepresentation from the rodent models hinder the translation from the laboratory to the clinic.

Evaluating motor function is a popular measure of functional recovery in animal models to assess the outcome of stem cell therapy [27-29]. This measure has proven to be a cost-effective approach given the reduced time and staff required to complete the motor task testing of the animals. Our research team also integrated cognitive function as a measure of functional outcome, given that stroke patients can also suffer from behavioral deficits. Contrary to motor function, this testing involves the time consuming task of organizing and retesting phases of experiments. Despite this, one must be willing to invest the time, staff, and labor to complete both motor and cognitive function tests in order to accurately evaluate the full range of therapeutic potential, safety and effectiveness of stem cell therapy. However, it is necessary to tailor the type of tests to the stroke model because certain models, such as the distal MCA ligation model that induces localized cortical damage, may not display as strong results as other models would.

\section{Conclusions}

\section{Challenges of translating animal studies of stem cell} therapies to clinical trials

As mentioned previously, there are several challenges in translating animal studies of stem cell therapies to clinical trials $[30,31]$. The combination of stem cell therapy and rehabilitation must be further examined and further development of transplant procedures, such as delivery route and repeated transplants, will accomplish optimal clinical benefits for stroke patients. Another challenge is the ability to recognize that specific animal models and functional endpoints reflect particular stroke symptoms and stages.

Several key clinical trials have helped shape the field of cell therapy in recent years, for example, the researchers 
who carried out the Parkinson's disease clinical trials [3236] providing the foundation for the first cell therapy in stroke patients [37, 38]. Their intracerebral transplantation of NT2N cells has provided a model for current clinical trials in chronic stroke patients [39-43]. Additionally, studies have explored the peripheral transplantation of stem cells for acute stroke patients [40,42], which has paved the way for future clinical studies.

Adult stem cells pose limited ethical barriers, which are principally related to the financial compensation related to conscientious clinics functioning as a 'medical tourism' industry. However, for ES cells, the main ethical dilemma remains the ethics of destroying embryos to harvest the stem cells. Also, whether this novel treatment will be covered by health insurance will be a major obstacle, as the therapy can cost hundreds of thousands of dollars. If not, then the challenge becomes how to provide this therapy to the financially struggling areas of our community.

Anticipated clinical news over the next few years on the continuing clinical trials will provide valuable information for cell therapy and its future applications. The original 'bench-to-bedside' approach, translating from the laboratory to the clinical setting must be accompanied by 'bedside-to-bench' assessments by re-examining and improving the transplant regimen in the lab to further the efficacy of additional clinical trials. However, this method is not well received by many in the industry and regulatory groups, causing the laborious efforts and significant delays in the lab to evaluate safety and efficacy to be directed towards that 'first and only' translation of stem cell therapy to the clinical setting in mind, overly cautious to avoid any failures that will result in setbacks throughout the field of regenerative medicine.

\footnotetext{
Abbreviations

AD: Alzheimer's disease; CNS: Central nervous system; ES: Embryonic Stem; IC: Intracerebral; iPSCs: Induced pluripotent stem cells; MCA: Middle cerebra artery; PD: Parkinson's disease; rsPSCs: Region-selective pluripotent stem cells; SVZ: Subventricular zone; TBI: Traumatic brain injury; VSELs: Very small embryonic-like
}

\section{Acknowledgement}

The authors thank Ms. Mia C. Borlongan for excellent technical assistance in the final preparation of this manuscript.

\section{Funding}

CVB is funded by NIH R01NS071956, NIH R01 NS090962, NIH R21NS089851, NIH R21 NS094087, DOD W81XWH-11-1-0634, and VA Merit Review 101 BX001407.

\section{Availability of data and materials}

This paper is a review article. Referred literature in this paper has been listed in the references part. The datasets supporting the conclusions of this article are available online by searching the PubMed. Some original points in this article come from the laboratory practice in our research centers and the authors' experiences.

\section{Authors' contributions}

The authors contributed equally to the conceptualization and write-up of this manuscript. All authors read and approved the final manuscript.

\section{Competing interests}

The authors declare no competing interests.

\section{Consent for publication}

All authors approved the publication of this manuscript.

\section{Ethics approval and consent to participate}

Not applicable.

Received: 14 July 2016 Accepted: 12 September 2016

Published online: 01 November 2016

\section{References}

1. Diamandis T, Borlongan CV. One, two, three steps toward cell therapy for stroke. Stroke. 2015;46(2):588-91. PubMed: 25503552.

2. Savitz SI, Cramer SC, Wechsler L. Stem cells as an emerging paradigm in stroke 3: enhancing the development of clinical trials. Stroke. 2014;45(2): 634-9. PubMed: 24368562.

3. Langhorne P, Bernhardt J, Kwakkel G. Stroke rehabilitation. Lancet. 2011; 377(9778):1693-702. PubMed: 21571152.

4. Van Praag H, Kempermann G, Gage F. Running increases cell proliferation and neurogenesis in the adult mouse dentate gyrus. Nat Neurosci. 1999;2: 266-70. PubMed: 10195220.

5. Mattson MP. Neuroprotective signalling and the aging brain: take away my food and let me run. Brain Res. 2000;886(1-2):47-53. PubMed: 11119686

6. Rodriguez JJ, Noristani HN, Olabarria M, et al. Voluntary running and environmental enrichment restores impaired hippocampal neurogenesis in a triple transgenic mouse model of Alzheimer's disease. Curr Alzheimer Res. 2011;8(7):707-17. PubMed: 21453244.

7. Zigmond MJ, Cameron JL, Leak RK, et al. Triggering endogenous neuroprotective processes through exercise in models of dopamine deficiency. Parkinsonism Relat Disord. 2009;3:S42-5. PubMed: 20083005.

8. Ploughman M, Attwood Z, White $\mathrm{N}$, et al. Endurance exercise facilitates relearning of forelimb motor skill after focal ischemia. Eur J Neurosci. 2007; 25(11):3453-60. PubMed: 17553014

9. Griesbach GS, Hovda DA, Molteni R, et al. Voluntary exercise following traumatic brain injury: brain-derived neurotrophic factor upregulation and recovery of function. Neuroscience. 2004;125(1):129-39. PubMed: 15051152.

10. Yasuhara T, Hara K, Matsukawa N, et al. Lack of exercise, via hindlimb suspension, impedes endogenous neurogenesis. Neuroscience. 2007;149(1): 182-91. PubMed: 17869433.

11. Nomura S, Kami K, Kawano F, et al. Effects of hindlimb unloading on neurogenesis in the hippocampus of newly weaned rats. Neurosci Lett. 2012;509(2):76-81. PubMed: 22206837.

12. Veena J, Shankaranarayana Rao BS, Srikumar BN. Regulation of adult neurogenesis in the hippocampus by stress, acetylcholine and dopamine. J Nat Sci Biol Med. 2011;2(1):26-37. PubMed: 22470231.

13. Han TK, Lee JK, Leem YH. Chronic exercise prevents repeated restraint stress-provoked enhancement of immobility in forced swimming test in overiectomized mice. Metab Brain Dis. 2015;30(3):711-8. PubMed: 25344674.

14. Barha CK, Brummelte S, Lieblich S, et al. Chronic restraint stress in adolescence differentially influences hypothalamic-pituitary-adrenal axis function and adult hippocampal neurogenesis in male and female rats. Hippocampus. 2011;21(11):1216-27. PubMed: 20665592.

15. Watson N, Ji X, Yasuhara T. No pain, no gain: lack of exercise obstructs neurogenesis. Cell Transplant. 2015;24(4):591-7. PubMed: 25806858.

16. Detante $O$, Jaillard A, Moisan A, et al. Biotherapies in stroke. Rev Neurol (Paris). 2014;170(12):779-98. PubMed: 25459115.

17. Kucia M, Reca R, Campbell FR, et al. A population of very small embryoniclike (VSEL) CXCR4(+)SSEA-1(+)Oct-4+ stem cells identified in adult bone marrow. Leukemia. 2006;20(5):857-69. PubMed: 16498386.

18. Wakao S, Kitada M, Kuroda Y, et al. Multilineage- differentiating stressenduring (MUSE) cells are a primary source of induced pluripotent stem cells in human fibroblasts. Proc Natl Acad Sci U S A. 2011;108(24):9875-80. PubMed: 21628574

19. Wu J, Okamura D, Li M, et al. An alternative pluripotent state confers interspecies chimaeric competency. Nature. 2015;521(7552):316-21. PubMed: 25945737.

20. Onteniente $B$. The multiple aspects of stroke and stem cell therapy. Curr Mol Med. 2013;13(5):821-31. PubMed: 23642063. 
21. Reyes S, Tajiri N, Borlongan CV. Development in intracerebral stem cell grafts. Exp Rev Neurother. 2015;15(4):381-93.

22. Borlongan CV, Hadman M, Sanberg CD, et al. Central nervous system entry of peripherally injected umbilical cord blood cells is not required for neuroprotection in stroke. Stroke. 2004;35(10):2385-9. PubMed: 15345799.

23. Tajiri N, Quach DM, Kaneko Y, et al. Behavioral and histopathological assessment of adult ischemic rat brains after intracerebral transplantation of NSI-556RSC cell lines. PLoS One. 2014;9(3):e9408.

24. Mitkari B, Kerkelä E, Nystedt J, et al. Advances in the Treatment of Ischemic Stroke. In: Balestrino M, editor. Toward a more effective intravascular cell therapy in stroke. 2012. p. 141-60.

25. Shindo A, Liang AC, Maki T, et al. Subcortical ischemic vascular disease: roles of oligodendrocyte function in experimental models of subcortical whitematter injury. J Cereb Blood Flow Metab. 2015;36(1):187-98.

26. Seo JH, Miyamoto N, Hayakawa $\mathrm{K}$, et al. Oligodendrocyte precursors induce early blood- brain barrier opening after white mater injury. J Clin Invest. 2013;123(2):782-6. PubMed: 23281396.

27. Lipsanen A, Jolkkonen J. Experimental approaches to study functional recovery following cerebral ischemia. Cell Mol Life Sci. 2011;68(18):3007-17. PubMed: 21626271.

28. Hicks A, Schallert T, Jolkkonen J. Cell-based therapies and functional outcome in experimental stroke. Cell Stem Cell. 2009;5(2):139-40. PubMed: 19664986.

29. Boltze J, Lukomska B, Jolkkonen J. Mesenchymal stromal cells in stroke: improvement of motor recovery or functional compensation? J Cereb Blood Flow Metab. 2014;34(8):1420-1. PubMed: 24849662.

30. Stroke Therapy Academic Industry Roundtable. Recommendations for standards regarding preclinical neuroprotective and restorative drugs. Stroke. 1999;30(12):2752-8. PubMed: 10583007.

31. Stem Cell Therapies as an Emerging Paradigm in Stroke Participants. Stem Cell Therapies as an Emerging Paradigm in Stroke (STEPS): bridging basic and clinical science for cellular and neurogenic factor therapy in treating stroke. Stroke J Cereb Circ. 2009;40(2):510-5.

32. Kordower JH, Freeman TB, Vingerhoets FJ, et al. Neuropathological evidence of graft survival and striatal reinnervation after the transplantation of fetal mesencephalic tissue in a patient with Parkinson's disease. N Engl J Med. 1995;332(17):1118-24. PubMed: 7700284.

33. Peschanski M, Defer G, N'Guyen JP, et al. Bilateral motor improvement and alteration of L-dopa effect in two patients with Parkinson's disease following intrastriatal transplantation of foetal ventral mesencephalon. Brain. 1994;117(pt 3):487-99. PubMed: 8032859.

34. Spencer DD, Robbins RJ, Naftolin F, et al. Unilateral transplantation of human fetal mesencephalic tissue into the caudate nucleus of patients with Parkinson's disease. N Engl J Med. 1992;327(22):1541-8. PubMed: 1435880.

35. Lindvall $\mathrm{O}$, Backlund EO, Farde $\mathrm{L}$, et al. Transplantation in Parkinson's disease: two cases of adrenal medullary grafts to the putamen. Ann Neurol. 1987;22(4):457-68. PubMed: 3435067.

36. Backlund EO, Granberg PO, Hamberger B, et al. Transplantation of adrenal medullary tissue to striatum in parkinsonism. J Neurosurgery. 1985;62(2):169-73.

37. Watson DJ, Longhi L, Lee EB, et al. Genetically modified NT2N human neuronal cells mediate long-term gene expression as CNS grafts in vivo and improve functional cognitive outcome following experimental traumatic brain injury. J Neuropathol Exp Neurol. 2003;62(4):368-80. PubMed: 12722829 .

38. Nelson PT, Kondziolka D, Wechsler $\mathrm{L}$, et al. Clonal human (hNT) neuron grafts for stroke therapy: neuropathology in a patient 27 months after implantation. Am J Pathol. 2002;160(4):1201-6. PubMed: 11943704.

39. Mack GS. ReNeuron and StemCells get green light for neural stem cell trials. Nat Biotechnol. 2011;29(2):95-7. PubMed: 21301419.

40. Savitz $\mathrm{SI}$, Misra V, Kasam M, et al. Intravenous autologous bone marrow mononuclear cells for ischemic stroke. Ann Neurol. 2011;70(1):59-69. PubMed: 21786299.

41. Jeong H, Yim HW, Cho YS, et al. Efficacy and safety of stem cell therapies for patients with stroke: a systematic review and single arm meta-analysis. Int J Stem Cells. 2014;7(2):63-9. PubMed: 25473443.

42. Lee JS, Hong JM, Moon GJ, et al. A long-term follow-up study of intravenous autologous mesenchymal stem cell transplantation in patients with ischemic stroke. Stem Cells. 2010;28(6):1099-106. PubMed: 20506226.

43. Kondziolka D, Steinberg GK, Wechsler L, et al. Neurotransplantation for patients with subcortical motor stroke: a Phase 2 randomized trial. J Neurosurg. 2005;103(1):38-45. PubMed: 16121971.

\section{Submit your next manuscript to BioMed Central and we will help you at every step:}

- We accept pre-submission inquiries

- Our selector tool helps you to find the most relevant journal

- We provide round the clock customer support

- Convenient online submission

- Thorough peer review

- Inclusion in PubMed and all major indexing services

- Maximum visibility for your research

Submit your manuscript at www.biomedcentral.com/submit 